\title{
Atlantic Ocean CARINA data: overview and salinity adjustments
}

\author{
T. Tanhua ${ }^{1}$, R. Steinfeldt ${ }^{2}$, R. M. Key ${ }^{3}$, P. Brown ${ }^{4}$, N. Gruber ${ }^{5}$, R. Wanninkhof ${ }^{6}$, F. Perez ${ }^{7}$, \\ A. Körtzinger ${ }^{1}$, A. Velo ${ }^{7}$, U. Schuster ${ }^{4}$, S. van Heuven ${ }^{8}$, J. L. Bullister ${ }^{9}$, I. Stendardo ${ }^{5}$, M. Hoppema ${ }^{10}$, \\ A. Olsen ${ }^{11,12}$, A. Kozyr ${ }^{13}$, D. Pierrot ${ }^{14}$, C. Schirnick ${ }^{1}$, and D. W. R. Wallace ${ }^{1}$ \\ ${ }^{1}$ Leibniz-Institut für Meereswissenschaften, Marine Biogeochemie, Kiel, Germany \\ ${ }^{2}$ Institut für Umweltphysik, Univerität Bremen, Bremen, Germany \\ ${ }^{3}$ Atmospheric and Oceanic Sciences Program, Princeton University, Princeton, NJ 08544, USA \\ ${ }^{4}$ School of Environmental Sciences, University of East Anglia, Norwich, NR4 7TJ, UK \\ ${ }^{5}$ Environmental Physics, Institute of Biogeochemistry and Pollutant Dynamics, ETH Zurich, Zurich, Switzerland \\ ${ }^{6}$ Atlantic Oceanographic and Meteorological Laboratory, NOAA, Miami Fl, 33149, USA \\ ${ }^{7}$ Instituto de Investigaciones Marinas - CSIC, Eduardo Cabello 6, 36208 Vigo, Spain \\ ${ }^{8}$ Department of Ocean Ecosystems, University of Groningen, Groningen, The Netherlands \\ ${ }^{9}$ Pacific Marine Environmental Laboratory/NOAA, 7600 Sand Point Way NE, Seattle, WA 98115-6349, USA \\ ${ }^{10}$ Alfred Wegener Institute for Polar and Marine Research, Postfach 120161, 27515 Bremerhaven, Germany \\ ${ }^{11}$ Bjerknes Centre for Climate Research, UNIFOB AS, Allégaten 55, 5007 Bergen, Norway \\ ${ }^{12}$ Department of Chemistry, University of Gothenburg, 41296 Göteborg, Sweden \\ ${ }^{13}$ Carbon Dioxide Information Analysis Center, Oak Ridge National Laboratory, Oak Ridge, TN 37922, USA \\ ${ }^{14}$ Cooperative Institute of Marine and Atmospheric Sciences, U. Miami, Miami, FL 33149, USA
}

Received: 17 June 2009 - Published in Earth Syst. Sci. Data Discuss.: 20 August 2009

Revised: 15 January 2010 - Accepted: 21 January 2010 - Published: 1 February 2010

\begin{abstract}
Water column data of carbon and carbon-relevant hydrographic and hydrochemical parameters from 188 previously non-publicly available cruise data sets in the Arctic Mediterranean Seas, Atlantic and Southern Ocean have been retrieved and merged into a new database: CARINA (CARbon dioxide IN the Atlantic Ocean). The data have gone through rigorous quality control procedures to assure the highest possible quality and consistency. The data for the pertinent parameters in the CARINA database were objectively examined in order to quantify systematic differences in the reported values, i.e. secondary quality control. Systematic biases found in the data have been corrected in the three data products: merged data files with measured, calculated and interpolated data for each of the three CARINA regions, i.e. the Arctic Mediterranean Seas, the Atlantic and the Southern Ocean. These products have been corrected to be internally consistent. Ninety-eight of the cruises in the CARINA database were conducted in the Atlantic Ocean, defined here as the region south of the Greenland-Iceland-Scotland Ridge and north of about $30^{\circ} \mathrm{S}$. Here we present an overview of the Atlantic Ocean synthesis of the CARINA data and the adjustments that were applied to the data product. We also report the details of the secondary QC (Quality Control) for salinity for this data set. Procedures of quality control - including crossover analysis between stations and inversion analysis of all crossover data - are briefly described. Adjustments to salinity measurements were applied to the data from 10 cruises in the Atlantic Ocean region. Based on our analysis we estimate the internal consistency of the CARINA-ATL salinity data to be $4.1 \mathrm{ppm}$. With these adjustments the CARINA data products are consistent both internally as well as with GLODAP data, an oceanographic data set based on the World Hydrographic Program in the 1990s, and is now suitable for accurate assessments of, for example, oceanic carbon inventories and uptake rates and for model validation.
\end{abstract}

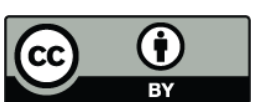

Correspondence to: T. Tanhua

(ttanhua@ifm-geomar.de)

Published by Copernicus Publications. 


\begin{tabular}{lllll}
\hline $\begin{array}{l}\text { Data Product } \\
\text { Parameter Name }\end{array}$ & $\begin{array}{l}\text { Data Product } \\
\text { Flag Name }\end{array}$ & $\begin{array}{l}\text { Exchange File } \\
\text { Parameter Name }\end{array}$ & $\begin{array}{l}\text { Exchange File } \\
\text { Flag Name }\end{array}$ & Units \\
\hline station & & STANBR & & \\
day & & DATE & & \\
month & & DATE & & \\
year & & DATE & & decimal degrees \\
latitude & & LATITUDE & & decimal degrees \\
$\begin{array}{l}\text { longitude } \\
\text { cruiseno }\end{array}$ & LONGITUDE & & meters \\
depth & & & & \\
temperature & & CTDTMP & & \\
salinity & sf & SALNTY & SALNTY_FLAG_W & \\
ctdsal & ctdsf & CTDSAL & CTDSAL_FLAG_W & \\
pressure & & CTDPRS & & decibars \\
\hline
\end{tabular}

For a complete list of all parameters available in CARINA see Key et al. (2009). Note the different names for the parameters in the individual cruise files and the merged data product.

\section{Data coverage and parameter measured}

Repository-Reference:

doi:10.3334/CDIAC/otg.CARINA.ATL.V1.0

Available at:

http://cdiac.ornl.gov/oceans/CARINA/Carina_inv.html

Coverage: $60^{\circ} \mathrm{S}-75^{\circ} \mathrm{N} ; 80^{\circ} \mathrm{W}-34^{\circ} \mathrm{E}$

Location Name: Atlantic Ocean

Date/Time Start: 1977-10-7

Date/Time End: 2006-02-02

\section{Introduction}

CARINA (CARbon IN the Atlantic Ocean) is a data set of carbon and carbon-relevant data from hydrographic cruises in the Arctic Mediterranean Seas, Atlantic and Southern Oceans. The project started as an informal, unfunded project in Delmenhorst, Germany, in 1999 during the workshop on " $\mathrm{CO}_{2}$ in the North Atlantic", with the main goal to create a uniformly formatted data set of carbon relevant variables in the ocean to be used for accurate assessments of oceanic carbon inventories and uptake rates. Collection of data and the quality control of the data have been a main focus of the CARINA project. Both primary and secondary quality control (QC) of the data have been performed. This report provides an overview of the Atlantic Ocean part of the CARINA data set and describes the consistency analysis of salinity for this data set. A more comprehensive description of the complete CARINA database can be found in Key et al. (2009) as well as in other, more specialized, papers in this special issue. CARINA consists of two parts: the first part is formed by the set of individual cruise files where all the data reported by the data originators are stored. The quality flags that accompany the data are in many cases those originally reported, and augmented by those assigned by R. Key. These files are in the so-called WHP-exchange format (http://whpo.ucsd.edu/format.html), where the first lines consist of the condensed metadata. There are essentially no calculated or interpolated values in the individual cruise files, with the exceptions of pressure calculated from depth and some bottle salinities that were taken from CTD salinity (hereafter ctdsal). No adjustments have been applied to any of these values with the exception that all $\mathrm{pH}$ measurements were converted to the seawater $\mathrm{pH}$ scale at $25^{\circ} \mathrm{C}$.

The second part of CARINA consists of three merged quality controlled and adjusted data files; one each for the Atlantic Ocean, Arctic Mediterranean Seas and Southern Ocean regions. Data that were found to be questionable (QC flag =3) or bad ( $\mathrm{QC}$ flag =4) have been removed in these data sets, but they are retained with appropriate flags in the individual cruise files. Occasionally all values of certain parameter obtained during a complete cruise was found to be questionable, and while these data have not necessarily been flagged as such in the individual cruise files, they have been removed from the data product. In these cases the flags in the individual files are the ones assigned during the primary QC. The merged files contain all the CARINA data and also include: 1) interpolated values for nutrients, oxygen and salinity if those data are missing and the interpolation could be made according to the criteria described in Key et al. (2009); and 2) calculated carbon parameters; e.g. if Total inorganic Carbon Dioxide $\left(\mathrm{TCO}_{2}\right)$ and Total Alkalinity (TA) were measured, $\mathrm{pH}$ was calculated, 3) instances where bottle salinity was missing or bad were replaced with ctdsal. In many cases there are additional parameters in the individual cruise files which have not undergone secondary QC, such as $\Delta{ }^{14} \mathrm{C}, \delta^{13} \mathrm{C}$ and $\mathrm{SF}_{6}$. These are included in the merged data files as well.

This paper is an overview of the quality control of the Atlantic Ocean subset of the CARINA data (i.e. CARINAATL) and contains the specifics of the salinity quality control. The Atlantic Ocean region of CARINA is loosely defined as the area between of the Greenland-Scotland Ridge and $30^{\circ} \mathrm{S}$, see Fig. 1. More details on other parameters for 


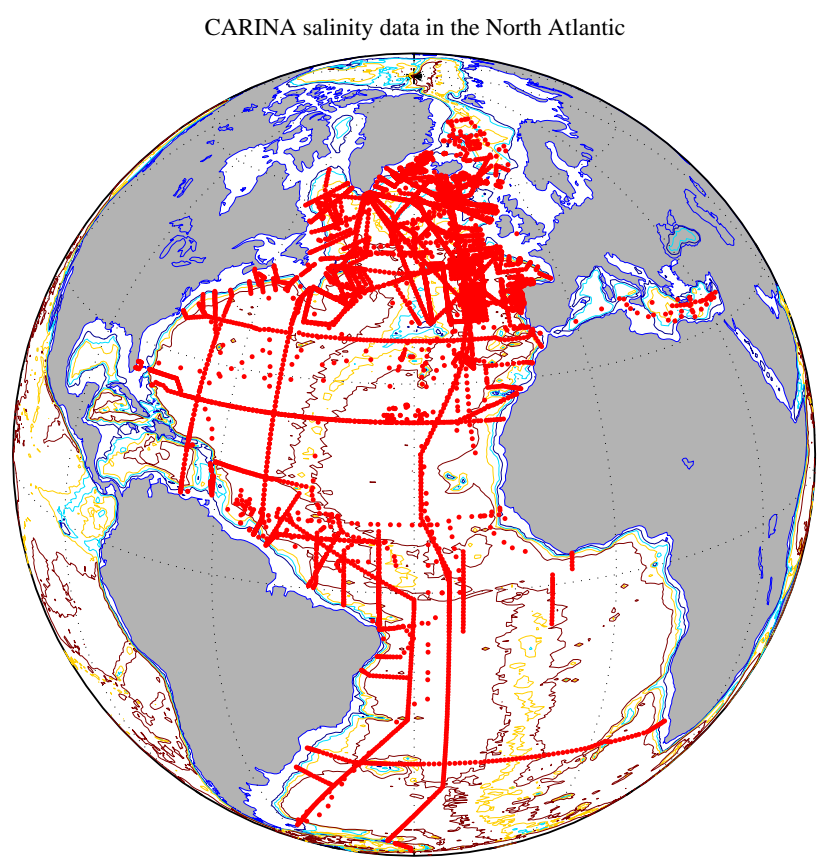

Figure 1. Map with the locations of all stations with salinity measurements in the CARINA Atlantic Ocean subset.

the Atlantic CARINA data can be found in reports by Tanhua et al. (2009a) for nutrients, Stendardo et al. (2009) for oxygen, Pierrot et al. (2010) for $\mathrm{TCO}_{2}$, Velo et al. (2009a) for alkalinity, Velo et al. (2009b) for $\mathrm{pH}$, and Steinfeldt et al. (2010) for CFCs. Table 1 presents a list of all cruises in the CARINA-ATL data set, along with the adjustments to the measured parameters that have been applied to the data product.

\section{Data provenance}

The CARINA database includes data and metadata from 188 oceanographic cruises/campaigns, of which five entries consist of multiple cruises. The Atlantic Ocean subset of the CARINA (CARINA-ATL) data set consists of 98 cruises/entries, of which one is a time series and further two are collections of multiple cruises conducted over several years within the framework of a common project. Additionally, six reference cruises were included in the secondary QC for CARINAATL to ensure consistency between CARINA and historical databases, in particular GLODAP (Global Ocean Data Analysis Project, Key et al., 2004). Five of the Atlantic Ocean region cruises are in common with the Southern Ocean region, and five are in common with the Arctic Mediterranean Seas region. These overlapping cruises ensure consistency between the three regions of the CARINA data set, but also lead to a slight extension of the geographical area covered. For the CARINA-ATL data set, a subset of cruises was identified as core cruises, see Table 1 . These were chosen based both on the geographical extent of the data set, i.e. cruises that cover
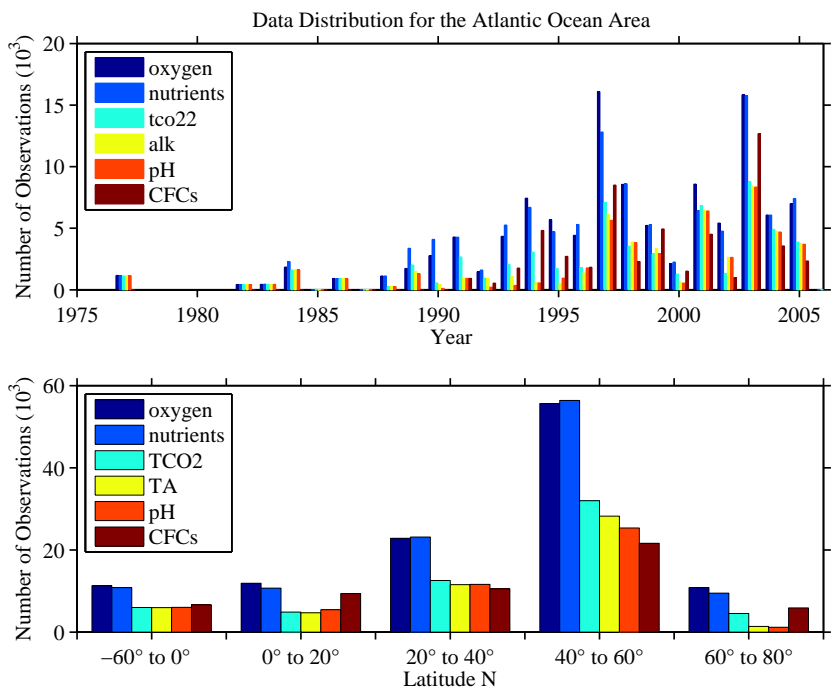

Figure 2. Data distribution for the CARINA-ATL data set. Top panel: Number of measurements during individual years, year markers in the centre of each group of observations. Lower panel: Distribution of measurements over latitudinal bands. Note that this plot includes interpolated data and calculated carbon parameters.

only a small and limited area would not be assigned as a core cruise, and an expected high quality of data, i.e. cruises with expected WOCE/CLIVAR quality, and metadata. Any offsets from these core cruises were weighed higher in the secondary QC. Note that even though all reference cruises were also selected as core cruises; several non-reference cruises were selected as core cruises.

The cruises included in the CARINA data products generally exclude those that were included in GLODAP. This was done primarily to facilitate later merging of these two data products. There are, however, 3 exceptions: 06MT19941012, 06MT19941115 and 74DI19970807 (Cruise Numbers 12, 13 and 171 respectively). These cruises were added to CARINA because additional parameters critical to the CARINA goals became available after GLODAP was published. The CARINA secondary QC, however, made full use of many of the GLODAP cruises and details are given in many of the accompanying papers in this issue.

Figure 1 show the position of all stations in the CARINAATL data set where salinity was measured, which encompasses all hydrographic stations in CARINA-ATL. Figure 2 displays the geographical and temporal coverage of the CARINA-ATL data. Most of the data are from the subpolar North Atlantic, and there are particularly large data gaps in the tropical and South-Eastern Atlantic Ocean. The CARINA-ATL data set covers the time period from 1978 to 2006, with most of the data from the mid 1990s to the mid 2000s. After salinity, nutrient and oxygen measurements show the highest incidence, followed by $\mathrm{TCO}_{2}$, Alkalinity and CFC data, although CFC data are particularly abundant for some specific regions. 
Table 1. This table lists all cruises in the CARINA dataset that are part of the Atlantic Ocean subset, and the additional reference cruises that were used for consistency with historical cruises (i.e. GLODAP). The table lists: CARINA cruise \#; EXPOCODE; cruises used as core cruises (1) in the analysis; and adjustment values applied to the data product, additive for: Salinity (ppm), ctdsal (ppm), total alkalinity $\left(\mu \mathrm{mol} \mathrm{kg}{ }^{-1}\right), \mathrm{TCO}_{2}\left(\mu \mathrm{mol} \mathrm{kg}{ }^{-1}\right)$, and $\mathrm{pH}$; multiplicative for: nitrate, phosphate, silicate, oxygen, $\mathrm{CFC} 12, \mathrm{CFC} 11, \mathrm{CFC} 113, \mathrm{CCl}{ }_{4}$. ND denotes "no data", i.e. the parameter was not measured, NC denotes "not considered", i.e. no adjustments was applied due to ambiguous evidence; "poor" indicates that the data quality was of low quality and is therefore not included in the data product.

\begin{tabular}{|c|c|c|c|c|c|c|c|c|c|c|c|c|c|c|c|}
\hline \# & EXPOCODE & core & salinity & ctd-sal & tco2 & alkalinity & $\mathrm{pH}$ & nitrate & phosphate & silicate & oxygen & F12 & F11 & F113 & $\mathrm{CCl} 4$ \\
\hline 5 & 06BE20001128 & 0 & -3 & -3 & ND & ND & $\mathrm{ND}$ & ND & ND & ND & ND & 1 & 1 & ND & ND \\
\hline 6 & 06GA19960613 & 0 & 10 & $\mathrm{NC}$ & 0 & ND & ND & ND & ND & ND & ND & ND & ND & ND & ND \\
\hline 7 & 06GA20000506 & 1 & 0 & $\mathrm{NC}$ & 0 & 0 & ND & 1 & 1 & 1.06 & 0.99 & ND & ND & ND & ND \\
\hline 8 & 06МT19920316 & 0 & $\mathrm{NC}$ & $\mathrm{NC}$ & poor & $\mathrm{NC}$ & ND & $\mathrm{NC}$ & $\mathrm{NC}$ & $\mathrm{NC}$ & ND & ND & ND & ND & ND \\
\hline 9 & 06МТ19920509 & 0 & -20 & $\mathrm{NC}$ & 0 & 0 & ND & 1 & 0.90 & 1 & 0.96 & ND & ND & ND & ND \\
\hline 10 & 06МT19920701 & 0 & 0 & $\mathrm{NC}$ & poor & 0 & ND & ND & ND & ND & ND & ND & ND & ND & ND \\
\hline 11 & 06МТ19940219 & 0 & 0 & $\mathrm{NC}$ & ND & ND & $\mathrm{ND}$ & ND & ND & ND & 1 & 1 & 1 & ND & ND \\
\hline 12 & 06МТ19941012 & 0 & 0 & $\mathrm{NC}$ & 0 & -25 & poor & 1 & 1 & 1 & 1 & 1 & 1 & 1 & 1 \\
\hline 13 & 06МТ19941115 & 1 & 0 & $\mathrm{NC}$ & 0 & ND & ND & 0.98 & 1 & 1 & 1 & 1 & 1 & ND & ND \\
\hline 14 & 06МТ19960613 & 0 & -10 & $\mathrm{NC}$ & 5 & 0 & ND & 1 & 1.15 & 1.11 & 0.98 & $\mathrm{ND}$ & ND & ND & ND \\
\hline 15 & 06МT19960910 & 0 & 0 & $\mathrm{NC}$ & ND & 0 & -0.007 & 1 & 1 & 1.05 & 0.985 & ND & ND & ND & ND \\
\hline 16 & 06MT19970107 & 0 & 0 & $\mathrm{NC}$ & $\mathrm{NC}$ & 0 & $\mathrm{NC}$ & 1 & 1.05 & 1.13 & 0.95 & ND & ND & ND & ND \\
\hline 17 & 06МТ19970515 & 1 & 10 & $\mathrm{NC}$ & 0 & 0 & ND & 1.05 & 0.95 & 1 & 0.99 & 1 & 1 & ND & ND \\
\hline 18 & 06МТ19970707 & 1 & 0 & $\mathrm{NC}$ & 0 & 0 & ND & 1.02 & ND & 1 & 1 & 1 & 1 & ND & ND \\
\hline 19 & 06МТ19970815 & 1 & 0 & $\mathrm{NC}$ & 0 & ND & ND & 1 & 1 & 1 & 1 & $\mathrm{ND}$ & 1 & ND & ND \\
\hline 20 & 06MT19990610 & 0 & ND & 5 & 0 & ND & 0 & 1 & 1 & 1 & 0.99 & 1 & 1 & ND & ND \\
\hline 21 & 06МТ19990711 & 0 & ND & 0 & 0 & ND & 0 & 1 & 1.04 & 1 & 0.99 & 1 & 1 & ND & ND \\
\hline 22 & 06МТ19990813 & 0 & 0 & $\mathrm{NC}$ & ND & ND & ND & ND & ND & ND & ND & 1 & 1 & ND & ND \\
\hline 23 & 06МТ20010507 & 0 & 0 & $\mathrm{NC}$ & 0 & 0 & -0.008 & 1 & 1.11 & 1 & 0.99 & 1 & 1 & ND & ND \\
\hline 24 & 06МТ20010620 & 0 & ND & 0 & ND & ND & ND & ND & ND & ND & ND & 1 & 1 & ND & ND \\
\hline 25 & 06МТ20010717 & 0 & 0 & $\mathrm{NC}$ & 0 & 0 & -0.005 & 1 & 1.25 & 1 & 1 & 1 & 1 & ND & ND \\
\hline 26 & 06МT20011018 & 0 & $\mathrm{NC}$ & $\mathrm{NC}$ & $\mathrm{NC}$ & $\mathrm{NC}$ & ND & ND & ND & ND & $\mathrm{NC}$ & $\mathrm{NC}$ & $\mathrm{NC}$ & $\mathrm{NC}$ & ND \\
\hline 27 & 06MT20020607 & 0 & 0 & 0 & ND & ND & ND & ND & ND & ND & 0.99 & 1 & 1 & ND & ND \\
\hline 28 & 06МТ20021013 & 0 & ND & 20 & $\mathrm{NC}$ & $\mathrm{NC}$ & ND & 1 & 1 & 0.92 & $\mathrm{NC}$ & ND & ND & ND & ND \\
\hline 29 & 06МТ20030626 & 0 & ND & 0 & ND & ND & ND & ND & ND & ND & ND & 1 & 1 & ND & ND \\
\hline 30 & 06МТ20030723 & 1 & 0 & 0 & 0 & 0 & 0 & 1 & 1 & 1 & 1 & 1 & 1 & ND & ND \\
\hline 31 & 06МТ20030831 & 0 & ND & 0 & ND & ND & ND & ND & ND & ND & ND & 1 & 1 & ND & ND \\
\hline 32 & 06МТ20040311 & 1 & ND & 0 & 0 & 0 & ND & 1 & 0.97 & 1 & 1 & 1 & 1 & ND & 1 \\
\hline 37 & 18HU19920527 & 0 & 0 & $\mathrm{NC}$ & -9 & ND & ND & 1 & 0.98 & 1 & 1 & 1.05 & 1 & ND & 1 \\
\hline 38 & 18HU19930405 & 0 & $\mathrm{NC}$ & $\mathrm{NC}$ & $\mathrm{NC}$ & ND & ND & $\mathrm{NC}$ & $\mathrm{NC}$ & $\mathrm{NC}$ & $\mathrm{NC}$ & ND & ND & ND & ND \\
\hline 39 & 18HU19930617 & 1 & 0 & $\mathrm{NC}$ & 0 & ND & ND & 1 & 1 & 1 & 1 & 1 & 1 & 1 & 1 \\
\hline 40 & 18HU19931105 & 0 & 0 & $\mathrm{NC}$ & 0 & ND & ND & 1 & 1 & 1 & 0.98 & 1 & 1 & poor & 1 \\
\hline 41 & 18HU19940524 & 0 & 0 & $\mathrm{NC}$ & 0 & ND & ND & 1 & 0.89 & 1 & 0.99 & 1 & 1.05 & poor & 1 \\
\hline 42 & 18HU19941012 & 0 & 0 & $\mathrm{NC}$ & 0 & ND & ND & 1 & 1 & 1 & 0.98 & poor & poor & 1 & 1 \\
\hline 43 & 18HU19950419 & 0 & 0 & $\mathrm{NC}$ & 0 & ND & ND & 1 & 1 & 1 & 1 & poor & 1 & 1 & poor \\
\hline 44 & 18HU19970509 & 1 & 0 & $\mathrm{NC}$ & 0 & 6 & ND & 1 & 1 & 1 & 1 & 1 & 1 & poor & poor \\
\hline 51 & 29CS19771007 & 0 & $\mathrm{NC}$ & ND & ND & $\mathrm{NC}$ & $\mathrm{NC}$ & $\mathrm{NC}$ & $\mathrm{NC}$ & $\mathrm{NC}$ & $\mathrm{NC}$ & ND & ND & ND & ND \\
\hline 52 & 29CS19930510 & 0 & 0 & $\mathrm{NC}$ & ND & 7 & 0.017 & 1.03 & 1 & $\mathrm{NC}$ & 1 & ND & ND & ND & ND \\
\hline 53 & 29GD19821110 & 0 & 0 & $\mathrm{NC}$ & ND & 0 & 0.024 & 1.02 & 0.98 & ND & 1.04 & ND & ND & ND & ND \\
\hline 54 & 29GD19831201 & 0 & $\mathrm{NC}$ & ND & ND & $\mathrm{NC}$ & $\mathrm{NC}$ & $\mathrm{NC}$ & $\mathrm{NC}$ & $\mathrm{NC}$ & $\mathrm{NC}$ & ND & ND & ND & ND \\
\hline 55 & 29GD19840218 & 0 & 0 & $\mathrm{NC}$ & ND & 6 & 0.023 & 0.95 & 1 & 1 & 1 & ND & ND & ND & ND \\
\hline 56 & 29GD19840711 & 0 & 0 & $\mathrm{NC}$ & ND & 0 & -0.017 & 1 & 1 & 1 & 0.98 & ND & ND & ND & ND \\
\hline 57 & 29GD19860904 & 0 & 0 & $\mathrm{NC}$ & ND & 6 & 0.032 & 1 & 1 & 1 & 1 & ND & ND & ND & ND \\
\hline 60 & 29HE19980730 & 0 & ND & -10 & 0 & 0 & 0 & 1.07 & poor & 1.14 & 1 & ND & ND & ND & ND \\
\hline 61 & 29HE20010305 & 0 & ND & 0 & ND & -6 & 0.005 & 1 & 1 & 1 & 0.99 & ND & ND & ND & ND \\
\hline 62 & 29HE20020304 & 1 & ND & 0 & ND & 0 & 0 & 1 & 1 & 1 & 1 & ND & ND & ND & ND \\
\hline 63 & 29HE20030408 & 0 & 0 & ND & $\mathrm{NC}$ & 0 & 0 & 1 & 1.12 & 1.08 & 1 & ND & ND & ND & ND \\
\hline 64 & $31 \mathrm{AN} 19890420$ & 0 & 0 & $\mathrm{NC}$ & 0 & -10 & ND & 1 & 1 & 1 & 1 & ND & ND & ND & ND \\
\hline 65 & 316 N19971005 & 0 & 0 & ND & 0 & 8 & ND & ND & ND & ND & 1 & ND & ND & ND & ND \\
\hline 66 & 316 N20010627 & 0 & 0 & ND & $\mathrm{NC}$ & $\mathrm{NC}$ & ND & ND & ND & ND & ND & ND & ND & ND & ND \\
\hline 68 & 316 N20030922 & 1 & 0 & ND & 0 & 0 & ND & 1 & 1 & 1 & 1 & 1 & 1 & 1 & 1 \\
\hline 69 & $316 \mathrm{~N} 20031023$ & 1 & 0 & ND & 0 & 0 & ND & 1 & 1.03 & 1 & 1 & 1 & 1 & 1 & 1 \\
\hline 71 & 32EV19910328 & 0 & 0 & ND & ND & ND & ND & 1.05 & 1 & 1 & 1 & ND & ND & ND & ND \\
\hline 81 & $32 \mathrm{OC} 19950529$ & 0 & 0 & ND & $\mathrm{NC}$ & ND & ND & ND & ND & ND & 1 & ND & ND & ND & ND \\
\hline 84 & 33LK19960415 & 0 & 0 & $\mathrm{NC}$ & 5 & ND & -0.018 & 1 & 1 & 1 & 1 & 1.1 & 1 & ND & ND \\
\hline 85 & 33RO19980123 & 1 & 0 & ND & 0 & 0 & 0 & 1 & 1 & 1 & 0.99 & 1 & 1 & 1 & 1 \\
\hline 86 & 33RO20030604 & 1 & 0 & ND & 0 & 0 & 0 & 1 & 1 & 1 & 1 & 1 & 1 & 1 & ND \\
\hline 87 & $33 \mathrm{RO} 20050111$ & 1 & 0 & ND & 0 & 0 & 0 & 1 & 1.03 & 1 & 1 & 1 & 1 & 1 & ND \\
\hline 89 & 33SW20010102 & 0 & $\mathrm{NC}$ & ND & $\mathrm{NC}$ & $\mathrm{NC}$ & ND & $\mathrm{NC}$ & $\mathrm{NC}$ & $\mathrm{NC}$ & $\mathrm{NC}$ & ND & ND & ND & ND \\
\hline 90 & 33SW20030418 & 0 & $\mathrm{NC}$ & ND & $\mathrm{NC}$ & $\mathrm{NC}$ & ND & ND & ND & ND & ND & ND & ND & ND & ND \\
\hline
\end{tabular}


Table 1. Continued.

\begin{tabular}{|c|c|c|c|c|c|c|c|c|c|c|c|c|c|c|c|}
\hline \# & EXPOCODE & core & salinity & ctd-sal & tco2 & alkalinity & $\mathrm{pH}$ & nitrate & phosphate & silicate & oxygen & F12 & F11 & F113 & $\mathrm{CCl} 4$ \\
\hline 91 & 34AR19970805 & 0 & ND & $\mathrm{NC}$ & ND & ND & ND & 1.05 & 1.04 & 1.15 & $\mathrm{NC}$ & 1 & 0.95 & 1 & 1 \\
\hline 92 & $35 \mathrm{~A} 320010203$ & 0 & 0 & ND & ND & 0 & 0 & 0.98 & 1 & ND & 1 & ND & ND & ND & ND \\
\hline 93 & $35 \mathrm{~A} 320010322$ & 0 & $\mathrm{NC}$ & ND & ND & 0 & 0 & 0.98 & 1 & ND & 1 & ND & ND & ND & ND \\
\hline 94 & 35LU19890509 & 0 & 0 & ND & ND & 0 & 0.024 & 1 & 1 & 1 & 1 & ND & ND & ND & ND \\
\hline 95 & 35LU19950909 & 0 & 0 & $\mathrm{NC}$ & 9 & ND & -0.028 & 1 & 1 & 1 & 1 & 1 & 0.9 & ND & ND \\
\hline 106 & 35TH19990712 & 0 & ND & 0 & 6 & -6 & -0.008 & 1 & poor & 1 & 1 & ND & 0.85 & ND & ND \\
\hline 107 & $35 \mathrm{TH} 20010823$ & 0 & $\mathrm{NC}$ & ND & ND & 0 & 0 & 1 & 0.96 & 1.07 & 1 & ND & ND & ND & ND \\
\hline 108 & 35 TH20020611 & 1 & 0 & ND & ND & 0 & 0 & 1 & 0.96 & 1 & 1 & ND & ND & ND & ND \\
\hline 109 & 35TH20040604 & 1 & 5 & ND & ND & 0 & 0 & 0.96 & 1.10 & 0.98 & 1 & ND & ND & ND & ND \\
\hline 113 & 49NZ20031106 & 1 & 0 & ND & 0 & 0 & 0 & 1 & 1 & 1 & 1 & 1 & 0.95 & ND & ND \\
\hline 125 & 58AA20010527 & 0 & 0 & ND & 0 & 0 & ND & ND & ND & ND & 1 & 0.95 & 1 & ND & ND \\
\hline 130 & 58JH19920712 & 0 & $\mathrm{NC}$ & ND & $\mathrm{NC}$ & ND & ND & $\mathrm{NC}$ & $\mathrm{NC}$ & $\mathrm{NC}$ & $\mathrm{NC}$ & ND & ND & ND & ND \\
\hline 135 & 58JH19940723 & 0 & $\mathrm{NC}$ & $\mathrm{NC}$ & $\mathrm{NC}$ & ND & ND & $\mathrm{NC}$ & poor & $\mathrm{NC}$ & $\mathrm{NC}$ & poor & poor & poor & poor \\
\hline 151 & 64PE19960618 & 0 & 0 & ND & ND & ND & ND & 1 & 1 & 1 & 1 & ND & ND & ND & ND \\
\hline 152 & 64PE20000926 & 0 & ND & 0 & 9 & ND & ND & 1 & 0.96 & 1 & 1.01 & ND & ND & ND & ND \\
\hline 153 & 64TR19890731 & 0 & 0 & ND & 0 & 14 & ND & 0.96 & poor & 1 & 1 & ND & ND & ND & ND \\
\hline 154 & 64TR19900417 & 0 & ND & 0 & poor & 14 & ND & 1 & 0.96 & 1 & 1 & ND & ND & ND & ND \\
\hline 155 & 64TR19900701 & 1 & 0 & 0 & 7 & ND & ND & 1 & 1 & 1 & 1.02 & ND & ND & ND & ND \\
\hline 156 & 64TR19900714 & 0 & 0 & ND & 0 & ND & ND & 1 & 1 & 1 & 1.015 & ND & ND & ND & ND \\
\hline 157 & 64TR19910408 & 1 & 0 & ND & 6 & ND & ND & 1 & 0.93 & 1 & 1.015 & ND & ND & ND & ND \\
\hline 158 & 67SL19881117 & 0 & $\mathrm{NC}$ & ND & ND & $\mathrm{NC}$ & $\mathrm{NC}$ & $\mathrm{NC}$ & ND & $\mathrm{NC}$ & $\mathrm{NC}$ & ND & ND & ND & ND \\
\hline 159 & 74AB19900528 & 0 & $\mathrm{NC}$ & ND & $\mathrm{NC}$ & ND & ND & 1.11 & 1 & $\mathrm{NC}$ & poor & ND & ND & ND & ND \\
\hline 160 & 74AB19910501 & 0 & 0 & $\mathrm{NC}$ & ND & 5 & 0.022 & 1 & 1 & 0.97 & 1 & ND & ND & ND & ND \\
\hline 161 & 74AB19910614 & 0 & $\mathrm{NC}$ & ND & $\mathrm{NC}$ & $\mathrm{NC}$ & ND & $\mathrm{NC}$ & $\mathrm{NC}$ & $\mathrm{NC}$ & ND & ND & ND & ND & ND \\
\hline 162 & 74AB19910712 & 0 & $\mathrm{NC}$ & ND & ND & ND & ND & $\mathrm{NC}$ & ND & 0.90 & 1.07 & ND & ND & ND & ND \\
\hline 164 & $74 \mathrm{AB} 20050501^{\mathrm{a}}$ & 0 & 0 & ND & 0 & 0 & ND & 0.98 & 0.97 & 0.93 & 0.94 & ND & ND & ND & ND \\
\hline 164 & $74 \mathrm{AB} 20050501^{\mathrm{b}}$ & 0 & 0 & ND & 0 & 0 & ND & 0.98 & 0.97 & 0.93 & 1 & ND & ND & ND & ND \\
\hline 165 & 74DI19890511 & 0 & 0 & $\mathrm{NC}$ & $\mathrm{NC}$ & ND & $\mathrm{NC}$ & $\mathrm{NC}$ & ND & ND & poor & ND & ND & ND & ND \\
\hline 166 & 74DI19890612 & 0 & 20 & ND & $\mathrm{NC}$ & ND & ND & poor & ND & poor & poor & ND & ND & ND & ND \\
\hline 167 & 74DI19890716 & 0 & 0 & ND & ND & ND & ND & poor & poor & 1 & poor & ND & ND & ND & ND \\
\hline 168 & 74DI19900425 & 0 & $\mathrm{NC}$ & $\mathrm{NC}$ & $\mathrm{NC}$ & ND & $\mathrm{NC}$ & $\mathrm{NC}$ & $\mathrm{NC}$ & $\mathrm{NC}$ & $\mathrm{NC}$ & ND & ND & ND & ND \\
\hline 169 & 74DI19900515 & 0 & 0 & $\mathrm{NC}$ & $\mathrm{NC}$ & ND & ND & $\mathrm{NC}$ & $\mathrm{NC}$ & $\mathrm{NC}$ & ND & ND & ND & ND & ND \\
\hline 170 & 74DI19900612 & 0 & 0 & $\mathrm{NC}$ & -7 & 15 & $\mathrm{NC}$ & 0.95 & 1.10 & poor & $\mathrm{ND}$ & ND & ND & ND & ND \\
\hline 171 & 74DI19970807 & 1 & 0 & ND & 0 & 0 & -0.005 & 1 & 0.97 & 1 & 1 & 1 & 1 & ND & ND \\
\hline 172 & 74DI19980423 & 1 & 0 & ND & ND & -8.5 & 0.018 & 1 & 1 & 1 & 1 & ND & ND & ND & ND \\
\hline 173 & 74DI20040404 & 1 & 0 & $\mathrm{NC}$ & 0 & 0 & ND & 0.97 & 1 & 0.98 & 1 & 1 & 1 & 1 & 1 \\
\hline 185 & IrmingerSea & 0 & $\mathrm{NC}$ & $\mathrm{NC}$ & $\mathrm{NC}$ & ND & ND & $\mathrm{NC}$ & $\mathrm{NC}$ & $\mathrm{NC}$ & $\mathrm{NC}$ & ND & ND & ND & ND \\
\hline 187 & OMEX1NA & 0 & ND & 0 & poor & poor & poor & 1 & 1 & 1 & 1 & ND & ND & ND & ND \\
\hline 188 & OMEX2 & 0 & 0 & 0 & ND & -8 & $\mathrm{ND}$ & 1 & 1 & $\mathrm{NC}$ & 1 & ND & ND & ND & ND \\
\hline ND & 316 N19970815 & 1 & 0 & $\mathrm{NC}$ & 0 & 0 & -0.01 & 1 & 1 & 1 & 1 & 1 & 1 & 1 & ND \\
\hline ND & 316N19970717 & 1 & 0 & $\mathrm{NC}$ & 0 & 0 & -0.009 & 1 & ND & 1 & 1 & 1 & 1 & ND & ND \\
\hline ND & 29HE19920714 & 1 & 0 & $\mathrm{NC}$ & poor & 0 & poor & 1 & poor & 0.97 & 1 & 1 & 1 & ND & ND \\
\hline ND & $316 \mathrm{~N} 19961102$ & 1 & 0 & $\mathrm{NC}$ & 0 & 0 & 0 & 1 & 0.96 & 1 & 1 & ND & ND & ND & ND \\
\hline ND & 323019940104 & 1 & 0 & $\mathrm{NC}$ & 0 & -8 & -0.009 & 1 & 1 & 0.98 & 1 & 1 & 1 & ND & ND \\
\hline ND & 317519930704 & 1 & 0 & $\mathrm{NC}$ & 0 & 0 & 0 & 1 & 1 & 1.03 & 1.02 & 1 & 0.95 & ND & ND \\
\hline
\end{tabular}

${ }^{a}$ Stations 1:43

b Stations 44:end

The individual cruises/campaigns are uniquely identified by an EXPOCODE. These identifiers consist of two characters identifying the country code of the research vessel, followed by the two character research vessel NODC (National Oceanographic Data Center) code. The last eight characters denote the starting date of the cruise (as YYYYMMDD). For instance, the EXPOCODE 06MT20040311 means that this cruise was conducted on the German (06) ship Meteor (MT) and that the cruise departed on 11 March 2004. In a few cases when the sailing date was unknown, the EXPOCODE is derived from the date of the first station occupied. The CARINA Atlantic Ocean collection contains data collected by several nations on a large number of research vessels in the framework of several nationally and internationally funded projects; see Table 2 for a listing. 
Table 2. List of ships that contribute to the CARINA Atlantic data set. Ships with an * symbol are included in the CARINA-ATL data set under the entry "OMEX1NA", NA denotes unknown EXPOCODE.

\begin{tabular}{lll}
\hline NODC Ship CODE & Ship name & Country \\
\hline $06 \mathrm{GA}$ & Gauss & Germany \\
$06 \mathrm{MT}$ & Meteor & Germany \\
18HU & Hudson & Canada \\
$29 \mathrm{CS}$ & Cornide de Saavedra & Spain \\
$29 \mathrm{GD}$ & Garcia del Cid & Spain \\
$29 \mathrm{HE}$ & Hesperides & Spain \\
$316 \mathrm{~N}$ & Knorr & USA \\
3175 & Baldrige & USA \\
3230 & Maurice Ewing & USA \\
$32 \mathrm{EV}$ & Endeavor & USA \\
$33 \mathrm{LK}$ & Edwin Link & USA \\
$33 \mathrm{RO}$ & Ronald H. Brown & USA \\
$33 \mathrm{SW}$ & Seward Johnson & USA \\
$34 \mathrm{AR}$ & Aranda & Finland \\
$35 \mathrm{~A} 3$ & L'Atalante & France \\
$35 \mathrm{LU}$ & LeNoroit & France \\
$35 \mathrm{TH}$ & Thalassa & France \\
$49 \mathrm{NZ}$ & Mirai & Japan \\
$58 \mathrm{JH}$ & Johan Hjort & Norway \\
$64 \mathrm{PE}$ & Pelagia & Netherlands \\
$64 \mathrm{TR}$ & Tyro & Netherlands \\
$67 \mathrm{SL}$ & Professor Siedlecki & Poland \\
$74 \mathrm{AB}$ & Charles Darwin & UK \\
$74 \mathrm{DI}$ & Discovery & UK \\
NA & Bjarni Saemundsson* & Iceland \\
$46 \mathrm{FR}$ & Arni Fridriksson* & Iceland \\
$06 \mathrm{PO}$ & Poseidon* & Germany \\
$11 \mathrm{BE}$ & Belgica* & Belgium \\
$06 \mathrm{AZ}$ & Valdivia* & Germany \\
NA & Madornina* & Spain \\
& &
\end{tabular}

The individual cruise tracks are shown in Fig. 3, along with the salinity profiles after application of the adjustments. Note that a common salinity range is used for easy comparison, but it causes the salinity data for the Mediterranean Sea to be off-scale.

\section{Computational analysis approach}

Our quality control procedures are comprised of two distinct steps. First the reported measurements are objectively studied in order to identify outliers and obvious errors, i.e. 1st level QC. Secondly, we quantify systematic differences in the reported values in a process called secondary QC. These QC processes were performed on the post-cruise data sets as reported by the data originators, and are distinct from the quality assurance (QA) procedures originally performed by each cruise measurement team.
The single most important tool in the secondary QC of the salinity data was the crossover analysis. Crossover analysis is an objective comparison of deep water data from one cruise with data from other cruises in the same area (e.g. Sabine et al., 1999; Gouretski and Jancke, 2001; Johnson et al., 2001; Sabine et al., 2005), see also http://cdiac.esd.ornl.gov/ oceans/glodap/crossover.html, where the concept was laid out. For the six reference cruises used in this study and for three cruises present in both CARINA and GLODAP, secondary QC has been performed previously (Gouretski and Jancke, 2001; Sabine et al., 2005), and adjustments were incorporated in the GLODAP data product. In Table 3 we have compared our results with those applied to GLODAP. Since there are differences in the use of additive and multiplicative adjustments between the work by Gouretski and Jancke (2001) and CARINA, the results are not directly comparable. Differences in adjustments between the two data products are discussed in this report, by Stendardo et al. (2009) and by Tanhua et al. (2009a).

Details on the methodology used in this work can be found in Tanhua et al. (2009b). Cruise tracks that crossed each other, or came within $\sim 120 \mathrm{~nm}$, were considered a crossover. For each crossover, comparisons of the salinity values were made on surfaces of equal pressure ( $\approx$ constant depth) at depths $>1500 \mathrm{~m}$ depth. The use of equal pressure surfaces as opposed to equal density surfaces for salinity crossovers is due to the direct influence of any salinity offsets to the density, see Tanhua et al. (2009b). The results of each crossover analysis are an offset and a standard deviation of the offset. These offsets and uncertainties were used to generate a set of suggested corrections for each cruise with a set of least square models, i.e. inversions, see Tanhua et al. (2009b). The corrections were critically examined with regards to local variability, time between the cruises and crossovers with core cruises by the team. After the crossover analysis, and aided by the corrections suggested by the inversion analysis, the offsets in measured salinity were carefully scrutinized for each cruise, and an adjustment was applied to the data product if all lines of evidence warranted such an adjustment. The adjustments were applied to the entire depth range of the cruise, but the adjustment can vary for parts of a cruise, Table 1. All suggested adjustments were vetted within the CARINA-ATL working group during a meeting in Paris in June 2008.

\section{Atlantic Ocean salinity analyses}

In the CARINA data set there are two different salinity entries: "salinity" and "ctdsal", where "salinity" refers to "bottle" salinity measured on board from discrete samples on water drawn from the water sampling bottles, whereas "ctdsal" refers to the equivalent salinity measurement derived from the CTD conductivity sensor at the depth the sampling bottle was "tripped". It was often difficult to unambiguously 

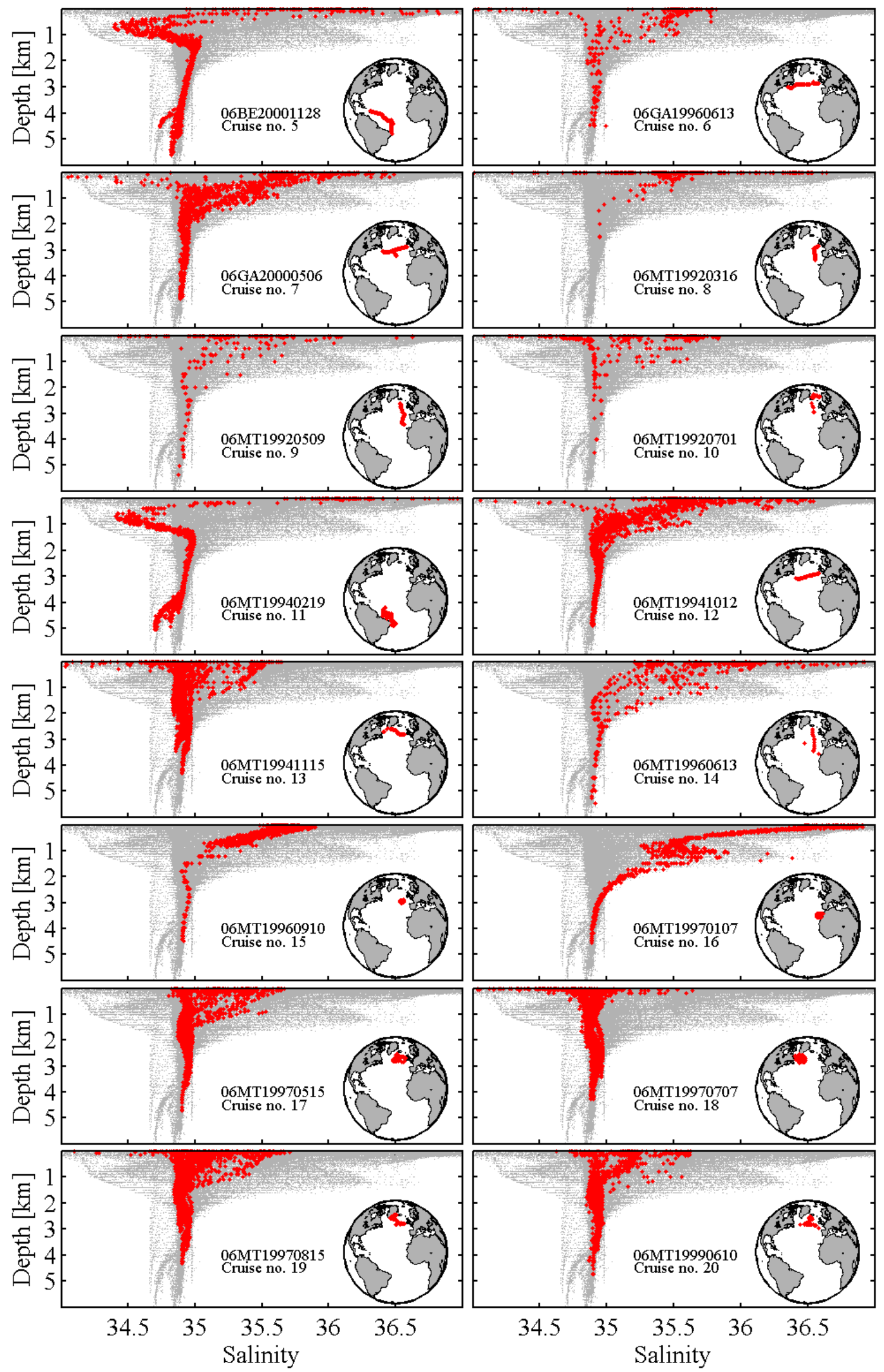

Figure 3. Salinity profiles and station locations of all the CARINA-ATL data; gray dots are all the salinity data; red dots the salinity belonging to that particular cruise. Note that these are the adjusted data. 

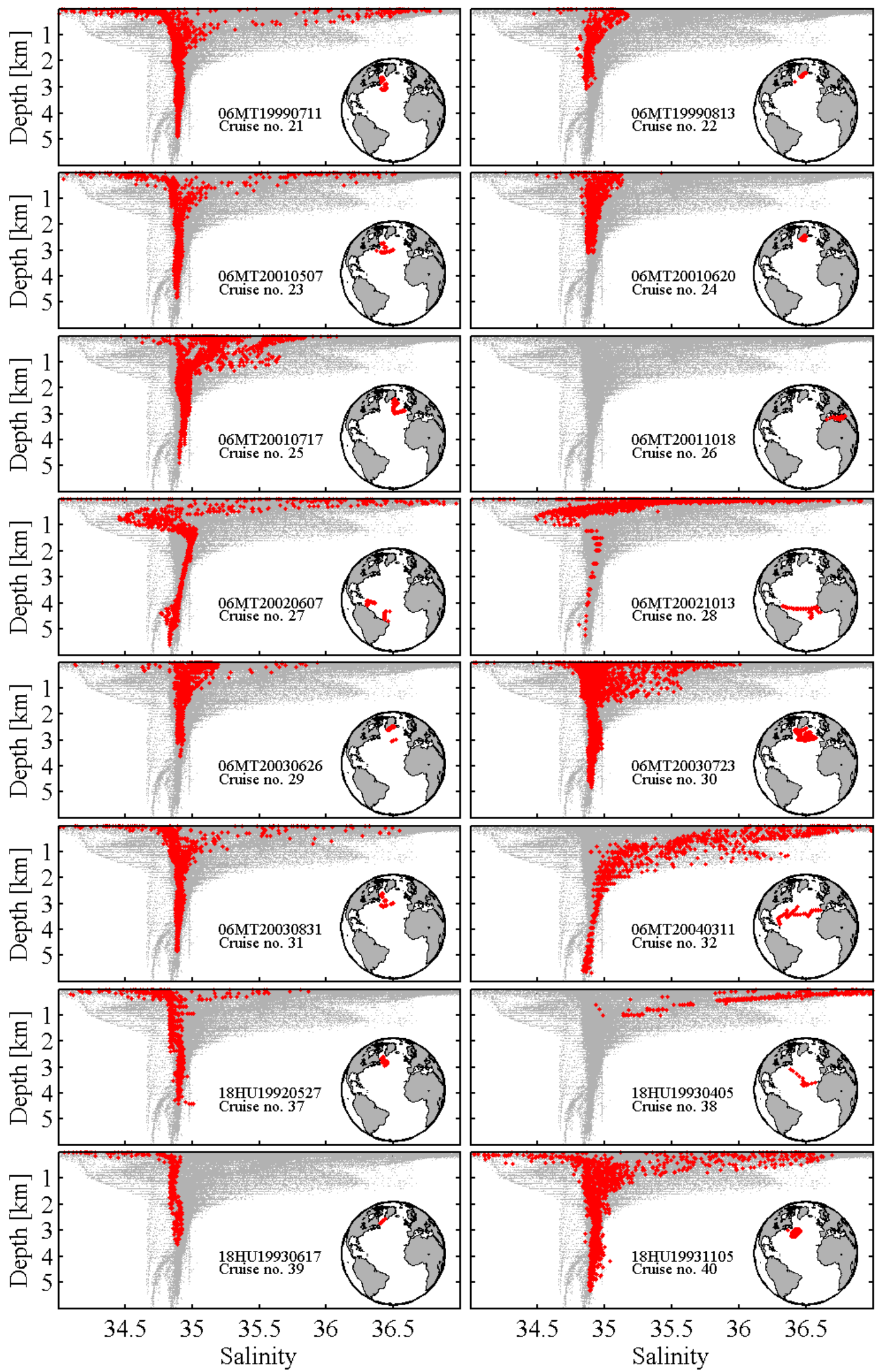

Figure 3. Continued. 

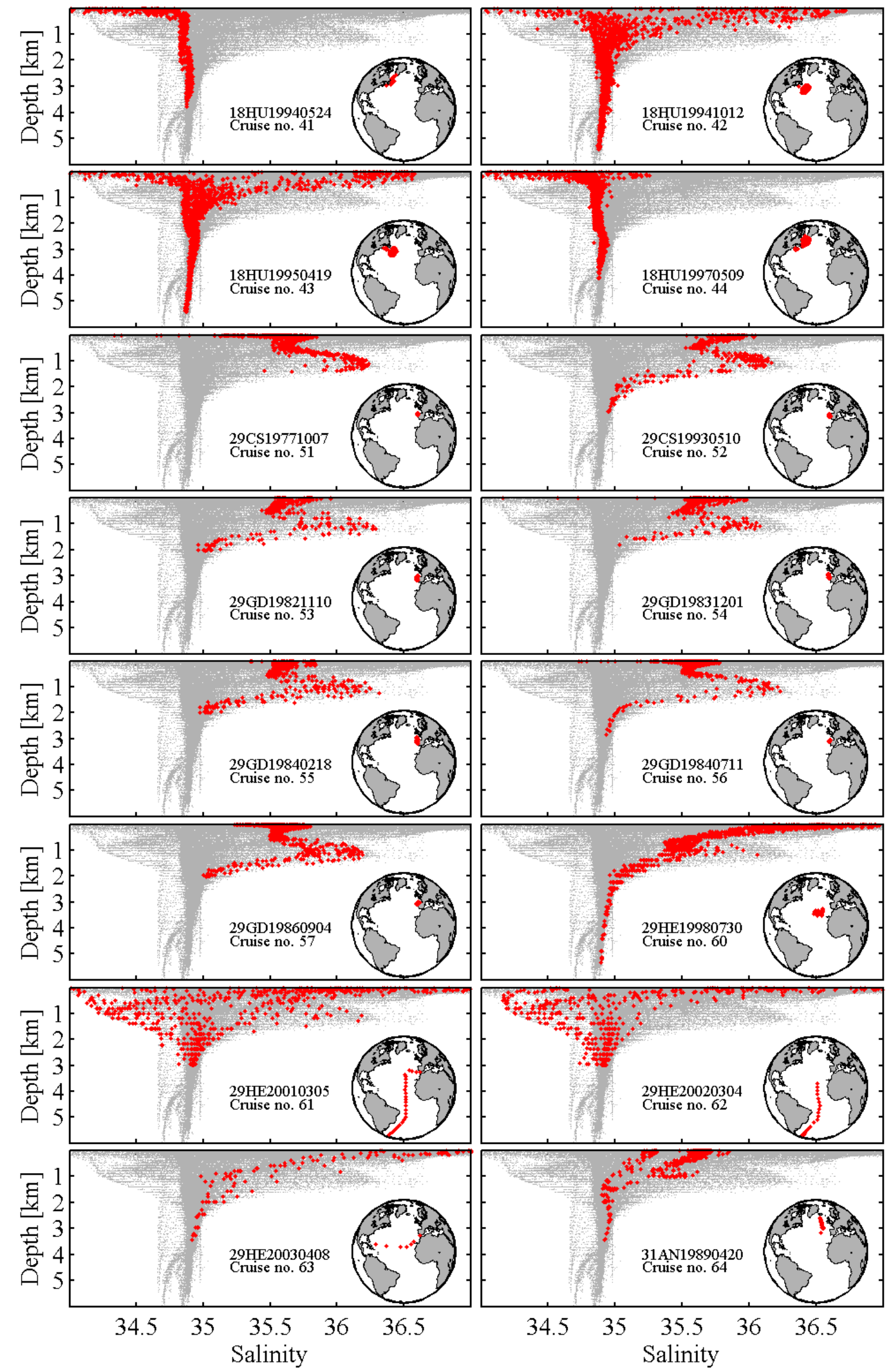

Figure 3. Continued. 

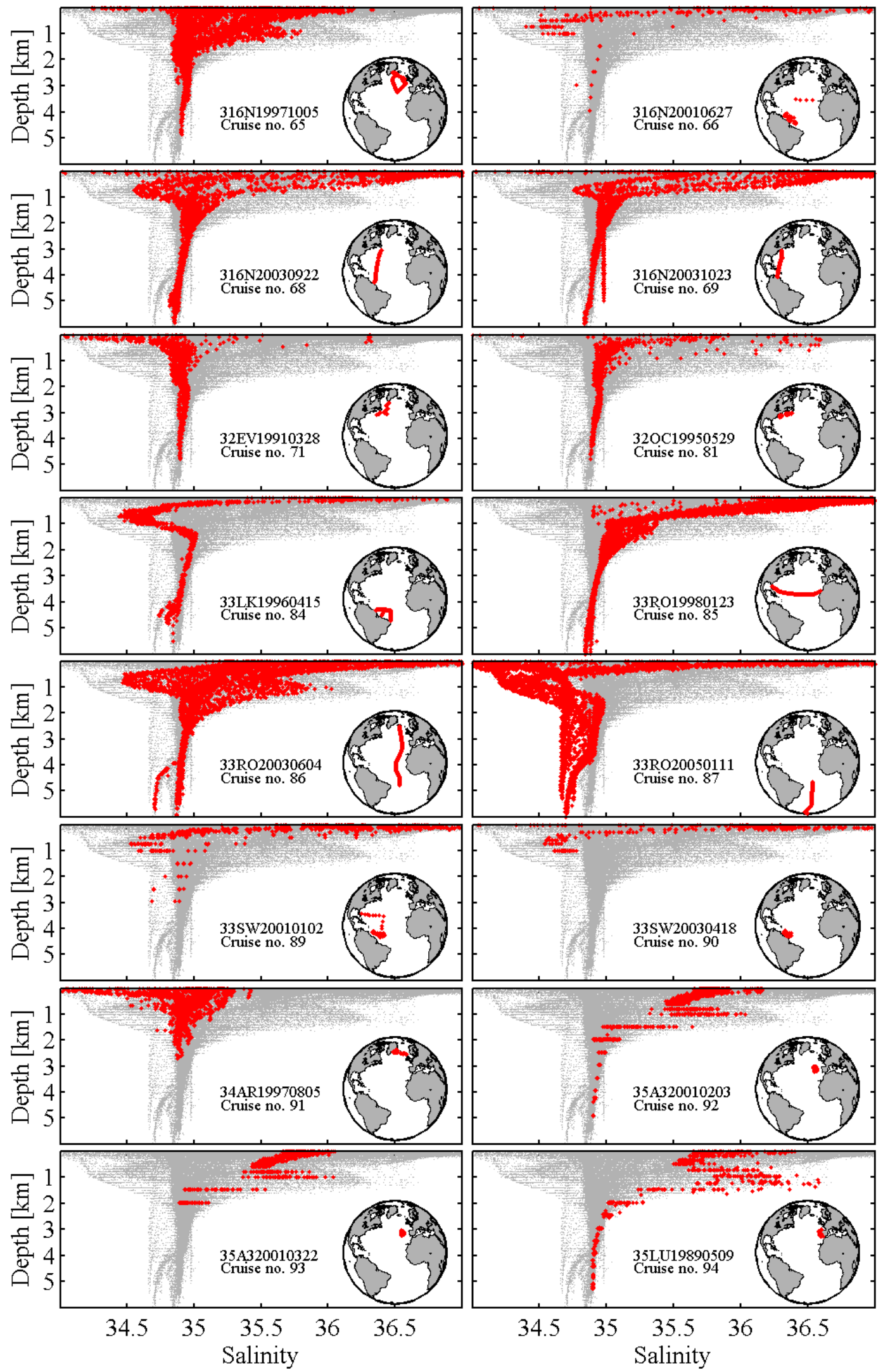

Figure 3. Continued. 

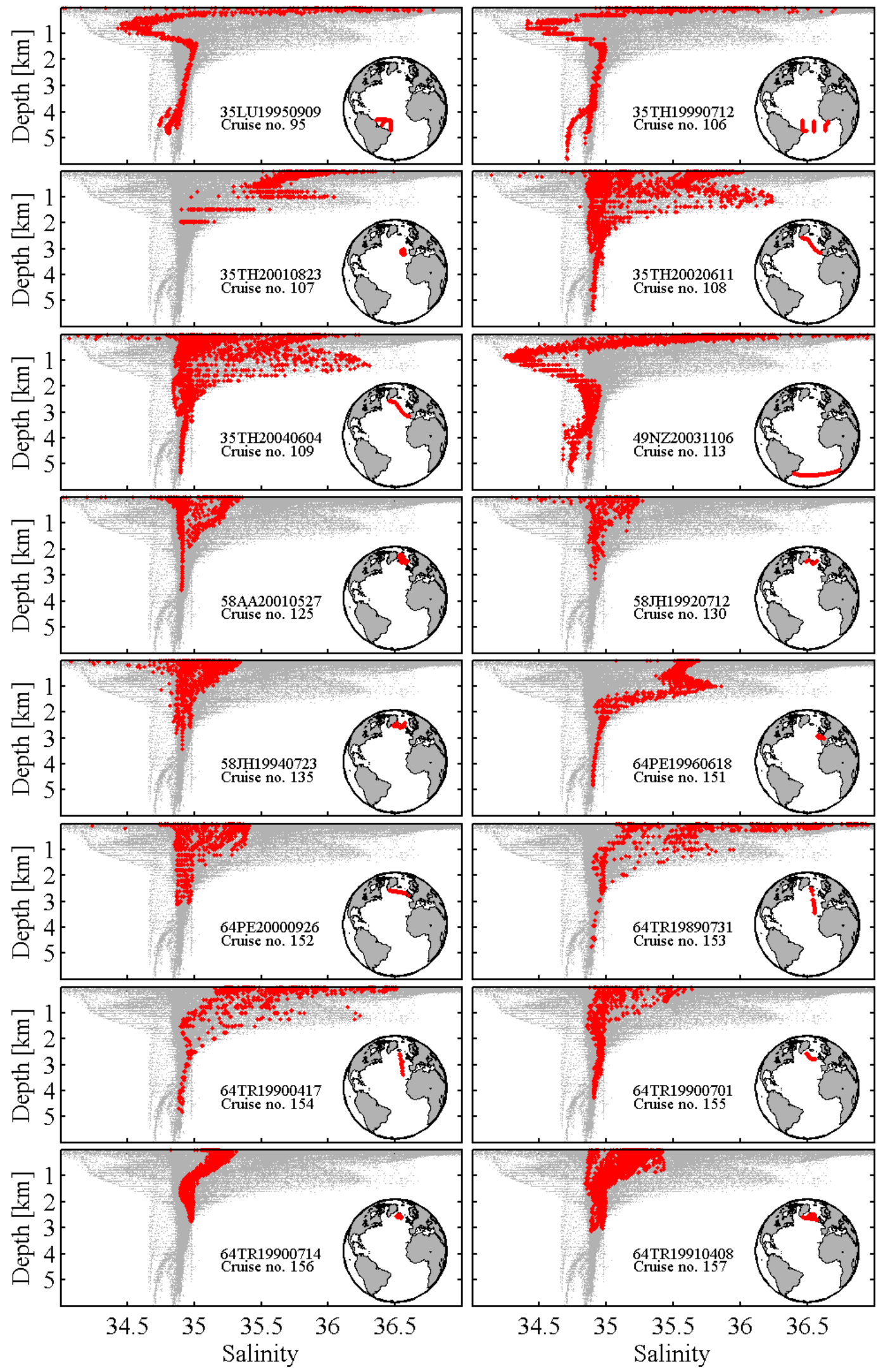

Figure 3. Continued. 

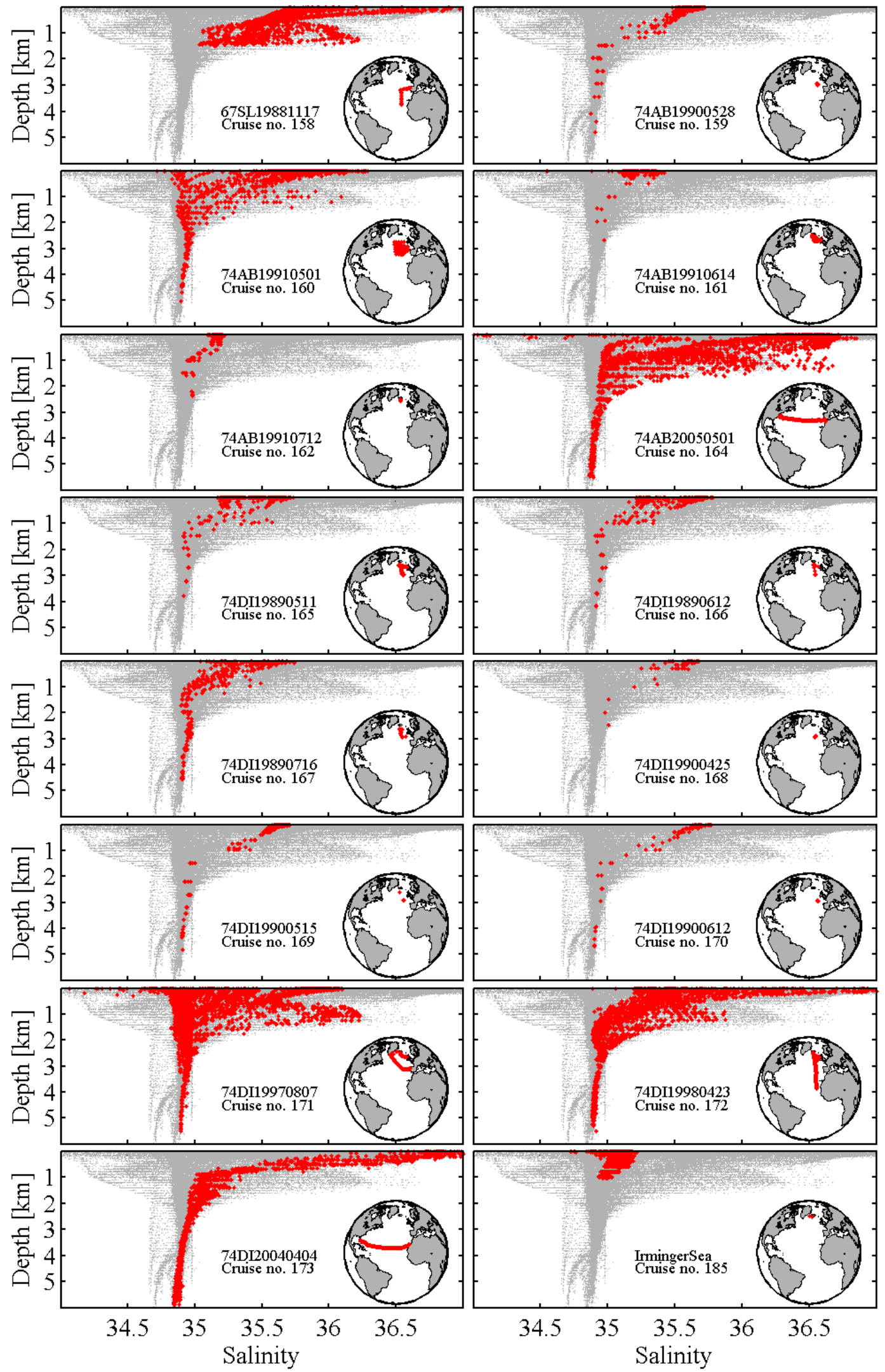

Figure 3. Continued. 

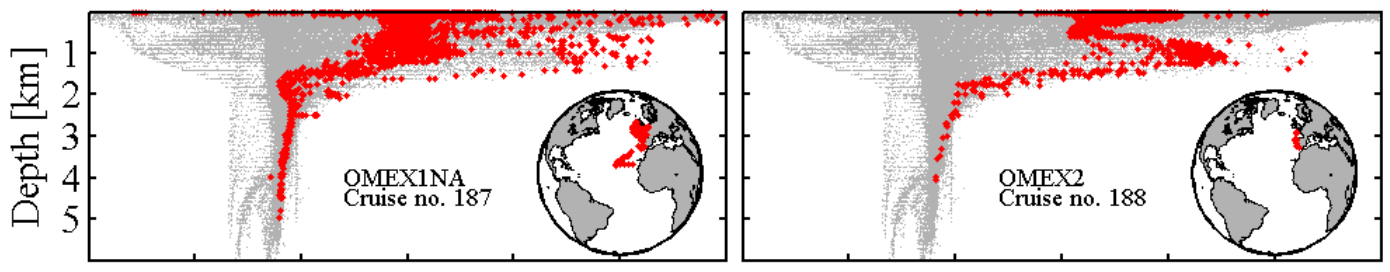

Figure 3. Continued.

Table 3. Table with comparison of previously applied adjustments for the reference cruises in CARINA-ATL; the first numbers are the adjustments suggested by the CARINA team, the number after the slash are the adjustments applied to the GLODAP data base (Gouretski and Jancke, 2001; Sabine et al., 2005). The cruises above the bold line are reference cruises (i.e. are not part of CARINA), the three cruises below the line are cruises that are included both in CARINA and GLODAP. The salinity adjustments are in ppm, all other adjustments in $\mu \mathrm{mol} / \mathrm{kg}$ (when not a multiplicative factor). Note that all adjustments to the GLODAP data are additive whereas the nutrients and oxygen corrections for CARINA are multiplicative. All adjustments different from 0 (or 1 for multiplicative adjustments) for CARINA are printed in bold letters.

\begin{tabular}{llllllll}
\hline Cruise & Salinity & $\mathrm{TCO}_{2}$ & Alk & Nitrate & Phosphate & Silicate & Oxygen \\
\hline 316N19970815 & $0 / 0.1$ & $0 / 0$ & $0 / 0$ & $1 /-0.37$ & $1 /-0.058$ & $1 / 0.0$ & $1 / 1.80$ \\
316N19970717 & $0 / 0.7$ & $0 / 0$ & $0 / 0$ & $1 /-0.08$ & ND/-0.042 & $1 /-0.8$ & $1 / 0.26$ \\
29HE19920714 & $0 /-0.3$ & Poor/0 & $0 / 0$ & $1 /-0.34$ & Poor/-0.03 & $\mathbf{0 . 9 7 / - 1 . 9}$ & $1 / 0.31$ \\
316N19961102 & 0 & $0 / 0$ & $0 / 0$ & $1 /-0.29$ & $\mathbf{0 . 9 6} /-\mathbf{0 . 0 4}$ & $1 / 0.6$ & $1 /-0.48$ \\
323019940104 & $0 /-1.8$ & $0 / 0$ & $0 / 0$ & $1 /-0.06$ & $1 /-0.024$ & $\mathbf{0 . 9 8} /-\mathbf{1 . 6}$ & $1 /-0.044$ \\
317519930704 & $0 /-1.5(-2.8)$ & $0 / 0(0)$ & $0 / 0(0)$ & $1 / 0(0)$ & $1 / 0.038(0.032)$ & $\mathbf{1 . 0 3 / 0 . 4}(\mathbf{2 . 6})$ & $\mathbf{1 . 0 2 / 0 ( 5 . 1 0 )}$ \\
\hline 06MT19941012 $^{2}$ & $0 /-0.6$ & 0/NA & $-25 / \mathrm{NA}$ & $1 / 0.07$ & $1 /-0.04$ & $1 / 1.8$ & $1 /-3.01$ \\
06MT19941115 & $0 / 1.5$ & 0/NA & NA & $0.98 /-0.79$ & $1 /-0.061$ & $1 / 0.7$ & $1 /-0.17$ \\
74DI19970807 & $0 / 2$ & 0/NA & 0/NA & $1 /-0.58$ & $\mathbf{0 . 9 7 / - 0 . 1 1 5}$ & $1 /-1.0$ & $1 /-6.79$ \\
\hline
\end{tabular}

${ }^{\text {a }}$ Station range for previous work is $1: 37$ (38:83).

distinguish between the two for some cruises due to lack of metadata, i.e. it is almost certain that some ctdsal values have been reported as "bottle" salinity. During the secondary QC we always used salinity if available, but inserted ctdsal values if salinity data were missing. Note that the typical differences between salinity and ctdsal (usually a few parts in 35 000) or the differences between uncorrected and corrected salinity (typically less than 10 parts in 35000 ) are relatively small, but within the cut-off limit of 0.005 salinity units $(=5 \mathrm{ppm})$ for adjustments to salinity. For most geochemical measurements which require a correction for salinity (or for density), these differences do not significantly impact the precision of the reported geochemical measurement. Following the salinity QC procedures, the adjustments are then either applied to: 1) salinity, if the secondary QC was solely based on the salinity values; 2) ctdsal if the secondary QC was based solely on ctdsal values; or 3 ) to both salinity and ctdsal if those values are consistent and the secondary QC was based on both values. For the merged data product, ctdsal values have been used to fill in gaps in the salinity values.

Additive adjustments were used for salinity, as opposed to linear correction factors applied to oxygen and nutrient data, since an offset in the reference material, or lack of correction to a reference material, is the most likely cause of the offsets, as discussed in Tanhua et al. (2009b). However, given the relatively limited range of salinity values encountered in the open ocean, multiplicative corrections would not have yielded significantly different results. With one exception (cruise 06BE20001128, see below), no adjustments smaller than 5 ppm (0.005 on the practical salinity scale PSS) were applied to the salinity, a threshold based on the typically reported values of precision of salinity measurements and the expected natural variability of salinity distribution in the deep water of the Atlantic Ocean.

Three lines of evidence were used for the determination of adjustments for the salinity values: the corrections suggested by the inversion; the average of the crossover offset for a particular cruise; and the results of crossovers with core cruises. The final decision to perform an adjustment was further based on considerations of known hydrographic features in the Atlantic Ocean. The cruises included in the analysis span a time frame of about two decades, which means that the observations used in the inversions could have been influenced by variability on annual to decadal time scales. Note that seasonal variability is most likely absent at depths greater than $1500 \mathrm{~m}$. For example, the salinity in the deep 


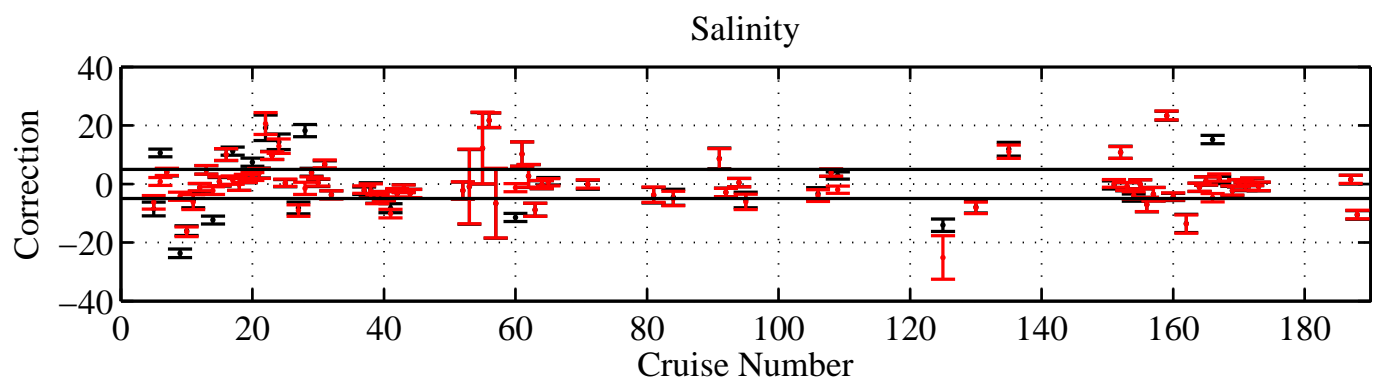

Figure 4. Corrections for the CARINA-ATL salinity data as suggested by two WDLSQ inversions. The black symbols are results obtained using original (i.e. unadjusted) data; the red symbols are obtained using the adjusted data set. The black horizontal lines denote the threshold of 5 ppm, no smaller adjustments were applied to the data.

waters of the Atlantic is influenced by decadal scale changes such as the depth and intensity of convection in the Labrador Sea, the salinity of the northern overflow waters, and the salinity of the Mediterranean outflow. The Labrador Sea convection reached its maximum depth during the first half of the 1990s, resulting in very fresh and cold Labrador Sea Water (Yashayaev et al., 2007). Later on, the convection was restricted to shallower depths, and the Labrador Sea Water became more saline due to mixing with other water masses advected into the Labrador Sea from surrounding areas. The northern overflow waters show a freshening trend from 1965 until 2000 (Dickson et al., 2002), but this long term trend is overlaid by sub-decadal salinity variations. The temporal and spatial salinity variability within the deep waters is most pronounced in the following areas, 1) in the vicinity of the northern overflows, 2) in the Labrador Sea, and 3) in areas influenced by the Mediterranean outflow, i.e. Meddies (e.g. McDowell and Rossby, 1978; Richardson et al., 2000). Along the Deep Western Boundary Current, the variability of water mass properties is still detectable, but the amount of variability becomes smaller southwards. By strictly following the results of the inversions, this variability could be erroneously removed from the data.

In the Eastern Atlantic south of the Iceland Basin and in the subtropical/tropical Atlantic remote from the western boundary, the variability of water mass properties is much smaller. Thus, if the inversion suggests an adjustment for a specific cruise in a region of high variability, it was checked whether crossovers of this certain cruise exist with other cruises in regions of lower variability. If these crossovers supported the result from the inversion, the inversion result was taken as basis for the adjustment. Otherwise no adjustment was applied, or the magnitude of the correction is modified compared to the inversion result.

As a last step in the secondary QC a second inversion was conducted using the adjusted CARINA-ATL data, and all remaining corrections larger than $5 \mathrm{ppm}$ were evaluated again. This process led to a small number of changes to the adjustments. All results and analyses made by the group

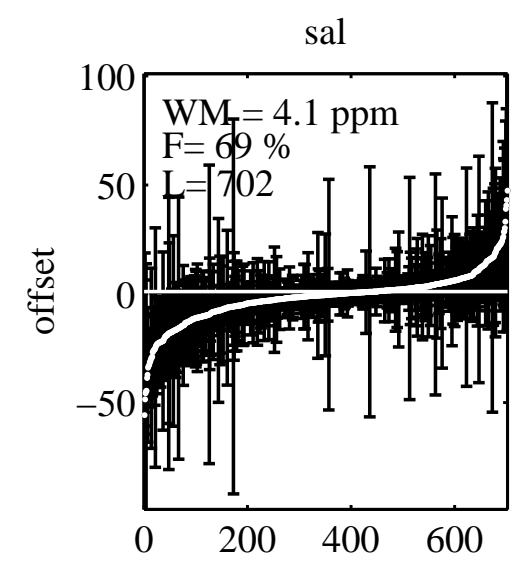

Figure 5. Offsets calculated for the salinity crossovers in the CARINA-ATL data after adjustments have been applied. WM: the weighted mean of the offsets (see text); $F$ : the percentage of offsets indistinguishable from 0 within their uncertainty; $L$ : the number of crossovers.

for the secondary QC (crossovers and inversions), including figures for each individual crossover can be found on the CARINA website (Tanhua et al., 2009b) at http://cdiac. ornl.gov/oceans/CARINA/CARINA_QC.html. In Fig. 4 we present the results of the WDLSQ (Weighted Dampened Least Squares) inversions of the crossover offsets before and after the adjustments were applied.

We used the offsets of the crossovers calculated for the adjusted data product to estimate the level of internal consistency of the salinity data, Fig. 5. We calculated the weighted mean (WM) using the absolute value of the offset $(D)$ of $L$ crossovers with the uncertainty $(\sigma)$ :

$\mathrm{WM}=\frac{\sum_{i=1}^{L} D(i) /(\sigma(i))^{2}}{\sum_{i=1}^{L} 1 /(\sigma(i))^{2}}$

Based on this analysis we estimate the internal consistency of the CARINA-ATL salinity data to $4.1 \mathrm{ppm}$. 
Table 4. Salinity corrections suggested by the WLSQ (Weighted Least Square) and WDLSQ (Weighted Damped Least Square) inversions used for the salinity adjustments for the Atlantic Ocean part of CARINA, and the adjustments that were actually applied to the data. Note that salinity is expressed in a thousands of a salinity (i.e. ppm). Only cruises for which the inversions suggest a significant (i.e. $>5 \mathrm{ppm}$ ) correction are listed. NC stands for "Not Considered" and no adjustment is applied, as described in the text.

\begin{tabular}{ccccc}
\hline CRUISE & EXPOCODE & \multicolumn{2}{c}{ Inversion Result } & Adjustment \\
$\#$ & & WLSQ & WDLSQ & \\
\hline 5 & 06BE20001128 & $-6.62 \pm 2.22$ & $-6.65 \pm 0$ & -3 \\
6 & 06GA19960613 & $12.65 \pm 1.14$ & $12.01 \pm 0.29$ & 10 \\
9 & 06MT19920509 & $-21.7 \pm \mathrm{g} 1.3$ & $-22.33 \pm 0.03$ & -20 \\
10 & 06MT19920701 & $-7.58 \pm 1.4$ & $-8.06 \pm 0.07$ & 0 \\
14 & 06MT19960613 & $-10.37 \pm 1.15$ & $-10.99 \pm 0.13$ & -10 \\
16 & 06MT19970107 & $11.91 \pm 1.88$ & $11.26 \pm 0.05$ & 0 \\
17 & 06MT19970515 & $13.12 \pm 1.23$ & $12.44 \pm 0.04$ & 10 \\
20 & 06MT19990610 & $9.33 \pm 1.18$ & $8.67 \pm 0.11$ & 5 \\
22 & 06MT19990813 & $18.23 \pm 4.27$ & $17.32 \pm 0$ & 0 \\
23 & 06MT20010507 & $11.65 \pm 1.22$ & $11.08 \pm 0.05$ & 0 \\
28 & 06MT20021013 & $20.37 \pm 1.96$ & $19.68 \pm 0.01$ & 20 \\
40 & 18HU19931105 & $-10.24 \pm 2.9$ & $-10.62 \pm 0$ & 0 \\
55 & 29GD19840218 & $16.35 \pm 12.23$ & $13.23 \pm 0$ & 0 \\
56 & 29GD19840711 & $23.76 \pm 2.42$ & $23.04 \pm 0$ & 0 \\
60 & 29HE19980730 & $-9.46 \pm 1.21$ & $-10.07 \pm 0.24$ & -10 \\
61 & 29HE20010305 & $12.49 \pm 4.09$ & $11.5 \pm 0$ & 0 \\
91 & 34AR19970805 & $7.36 \pm 3.48$ & $6.75 \pm 0$ & NC \\
109 & 35TH20040605 & $4.98 \pm 1.02$ & $4.32 \pm 0.12$ & 5 \\
152 & 64PE20000926 & $12.7 \pm 1.95$ & $12.03 \pm 0.01$ & 0 \\
159 & 74AB19900528 & $25.23 \pm 1.37$ & $24.56 \pm 0.1$ & NC \\
162 & 74AB19910712 & $-14.29 \pm 3.07$ & $-14.75 \pm 0$ & NC \\
166 & 74DI1980612 & $17.17 \pm 1.28$ & $16.52 \pm 0.07$ & 20 \\
188 & OMEX2 & $-8.66 \pm 1.31$ & $-9.33 \pm 0.22$ & 0 \\
& & & &
\end{tabular}

\subsection{Salinity adjustments}

In this section we present evidence supporting the adjustments applied to the NA salinity data set. Cruises where large corrections were implied by the inversions but were not applied are discussed as well. CARINA-ATL cruises not discussed in this section all have salinity data consistent with the majority of the CARINA-ATL cruises and the reference cruises. Corrections suggested by the inversions used for this analysis and the adjustment that were applied to salinity data are listed in Table 4 . The adjustments suggested to salinity for the 9 GLODAP cruises included in the CARINA 2nd QC are all smaller than $5 \mathrm{ppm}$, with one exception.

A crossover results in an offset for the cruise of interest (cruise A) relative to another cruise (cruise B), i.e. offset $=$ cruise $A$-cruise $B$. Thus if the offset is negative, the values from cruise A is lower than those from cruise B. Similarly, if the average of all crossovers for cruise $\mathrm{A}$ is negative, the values from cruise $A$ are lower than the values from other cruises in the area. The inversion process results in a suggestion for a correction to cruise A. If cruise $\mathrm{A}$ is lower than other cruises in the area, the correction will most likely be positive, i.e. the data from cruise A will have to be corrected upwards for consistency with other cruises. When we discuss adjustment, we refer to the correction that was actually applied to the data.

\section{BE20001128, cruise \#5}

The inversion suggests a correction of $-6 \mathrm{ppm}$. The offsets for the crossovers are, however, only in the range between 0 and $4 \mathrm{ppm}$. As this is a tropical Atlantic cruise, the deep water crossovers are only slightly influenced by temporal salinity changes. A correction of $-3 \mathrm{ppm}$ has been suggested before by an independent quality control from a repeated section along $16^{\circ} \mathrm{N}$ (Steinfeldt, unpublished data). The suggested correction may be due to a salinity reference material batch problem during cruise 06BE20001128. Based on this evidence, an adjustment of -3 ppm was applied to the salinity and ctdsal data.

\section{GA19960613, cruise \#6}

The inversions suggest corrections between 12 and $13 \mathrm{ppm}$. All crossovers in the eastern Atlantic have offsets ranging from $-10 \mathrm{ppm}$ and $-15 \mathrm{ppm}$, independent of the time of the cruise. In the western Atlantic, the discrepancies of the crossovers are larger, but this is not taken into account due to the temporal variability in this region. Based on this evidence, an adjustment of $10 \mathrm{ppm}$ was applied to the salinity data.

\section{MT19920509, cruise \#9}

The crossover analysis indicates that the salinity is 10 $30 \mathrm{ppm}$ too high. Some crossovers involve cruises conducted a long time after this cruise, but as they are located within the North Eastern Atlantic, the temporal variability should be small. The inversion suggests a correction of $-20 \mathrm{ppm}$, which is well within the range of the offsets from the crossovers. Based on this evidence, an adjustment of $-20 \mathrm{ppm}$ was applied to the salinity data.

\section{MT19920701, cruise \#10}

The inversions suggest a correction of $-8 \mathrm{ppm}$, but there are only a few deep data south of the Scotland-Iceland ridge with high variability in the offsets. For instance, the crossover with the nearly synoptic 316N200310236 shows no offset; neither do the crossovers with the Nordic Seas cruises. Based on this evidence, no adjustment was applied to the salinity data.

\section{MT19960613, cruise \#14}

The inversions suggest a correction of $-10 \mathrm{ppm}$ for this cruise. Most crossovers show an offset of about 10, at least 
in the deep water range below the Mediterranean outflow where the temporal variability is large. One exception is the crossover with 06MT20030723, with an offset between 15 and $20 \mathrm{ppm}$. Based on this evidence, an adjustment of $-10 \mathrm{ppm}$ was applied to the salinity data.

\section{MT19970107, cruise \#16}

Only a few crossovers exist for 06MT19970107, all of which are all located south of the Mediterranean outflow. The inversions suggest a correction on the order of $10 \mathrm{ppm}$. The depth structures of the crossovers are such that the differences with the other cruise are decreasing with depth, where the influence of the Mediterranean water is smaller. The few deep profiles in the crossovers are not sufficient to determine an offset for this cruise. Based on this evidence, no adjustment was applied to the salinity data.

\section{MT19970515, cruise \#17}

The inversions suggest a correction of $10 \mathrm{ppm}$. This agrees with most of the crossovers in the eastern North Atlantic. Only the crossovers directly south of Iceland have a higher offset, but also a large spread of the salinity data. Based on this evidence, an adjustment of $10 \mathrm{ppm}$ was applied to the salinity data.

\section{MT19990610, cruise \#20}

Only ctdsal data are available for this cruise. The mean offset and the inversion results indicate that the salinity is about $10 \mathrm{ppm}$ too low. For the adjustment, however, we follow the crossovers from the deep North Eastern Atlantic since the variability is lower there. These have an offset of only $-5 \mathrm{ppm}$. Based on this evidence, an adjustment of $5 \mathrm{ppm}$ was applied to the ctdsal data.

\section{MT19990813, cruise \# 22}

This cruise was conducted in the Irminger Sea where high temporal variability is expected. Although the mean of the crossover offsets is $-17 \mathrm{pm}$ and the inversions suggest a correction of $18 \mathrm{ppm}$; this might all be due to natural variability. Based on this evidence, no adjustment was applied to the salinity data.

\section{MT20010507, cruise \#23}

The single crossover results suggest an offset of about $-10 \mathrm{ppm}$, which is also reflected in the correction suggested by the inversions. However, the data are from the North Western Atlantic only, where the variability of water mass properties even in the deep water is large. Moreover, 2001 was the year with the lowest salinity in the DSOW in the
Labrador Sea, which may explain the offset in the crossovers towards the other cruises. Based on this evidence, no adjustment was applied to the salinity data.

\section{MT20021013, cruise \#28}

Only ctdsal data are available for this cruise, and only two crossovers exist. These are both located in the tropical Atlantic, and both have an offset of around $-20 \mathrm{ppm}$. This value is also reflected in the $20 \mathrm{ppm}$ correction suggested by the inversion. Based on this evidence, an adjustment of $20 \mathrm{ppm}$ was applied to the ctdsal data.

\section{HU19931105, cruise \#40}

The inversion result and the mean of the crossovers suggest that the salinity for this cruise is about $10 \mathrm{ppm}$ too high. However, the data are from the North Western Atlantic where the variability of water mass properties is large. This is also reflected within the crossovers, where the salinity offsets varies with depth, i.e. water mass, so that no constant offset can be determined. Based on this evidence, no adjustment was applied to the salinity data.

\section{GD19840218 and 29GD19840711, cruises \#55 and 56}

Both cruises are located close to the Mediterranean outflow region, where the spatial and temporal variability of salinity is extremely large. There are only very few data points deeper than $2000 \mathrm{~m}$, below which the influence of the Mediterranean waters decreases. Based on the lack of information, no adjustment was applied to the salinity data.

\section{HE19980730, cruise \#60}

Only ctdsal data are available for this cruise. The crossovers indicate a salinity offset between 5 and $10 \mathrm{ppm}$. A correction of this magnitude is supported by the inversions. The data are from the Eastern Subtropical Atlantic, where the variability of salinity is low, at least below the Mediterranean outflow layer. Based on this evidence, an adjustment of $-10 \mathrm{ppm}$ was applied to the ctdsal data.

\section{HE20010305, cruise \#61}

While some of the crossovers for this cruise have an offset, they are mostly located close to the Mediterranean outflow region. The crossovers from the deep tropical Atlantic, on the other hand, reveal only small offsets, and we put more weight on these crossovers in the analysis. Based on this evidence, no adjustment was applied to the salinity data. 


\section{AR19970805, cruise \#91}

This cruise covers the region north and south of the overflows from the Nordic Seas to the Atlantic, which is a region with large variability of water mass properties. Some crossovers have a positive offset, others a negative offset, which can be ascribed to this variability. Based on this variability, adjustments were not considered for salinity.

\section{TH20040605, cruise \#109}

The mean salinity offset of all crossovers is almost zero for this cruise, but the crossovers from the North Eastern Atlantic all have a negative offset. The inversions suggest a correction of about $5 \mathrm{ppm}$. Based on this evidence, an adjustment of $5 \mathrm{ppm}$ was applied to the salinity data.

\section{AA20010527, cruise \#125}

The analysis of salinity data in the Nordic Seas from this cruise showed no significant offset, see Olsen et al. (2009). The inversion for the NA region uses data close to the Greenland-Scotland ridge, whose results are not used due to the large variability. Based on this evidence, no adjustment was applied to the salinity data.

\section{JH19920712, cruise \#130}

This cruise is from the Greenland-Scotland ridge, an area with very large variability. Therefore, adjustments were not considered for salinity.

\section{JH19940723, cruise \#135}

This cruise is from the Greenland-Scotland ridge, an area with very large variability. Therefore, adjustments were not applied for salinity.

\section{64PE20000926, cruise \#152}

Both the mean of the crossovers and the inversion suggests that the salinity should be adjusted by about $10 \mathrm{ppm}$. However, the cruise was conducted in the Northern East Atlantic, where the variability of the ISOW is still pronounced. Some crossovers have mean offsets smaller than -5 ppm in the deep water. Based on this evidence, no adjustment was applied to the salinity data.

\section{AB19900528, cruise \#159}

This cruise covers a region influenced by the Mediterranean outflow. A salinity offset which is not impacted by natural variability can thus only be determined from profiles deeper than about $2000 \mathrm{~m}$. However, only five such profiles exist for this cruise, and they have a large spread in their salinity values, which makes the determination of an offset problematic. Based on this evidence, adjustments were not considered for salinity.

\section{AB19910712, cruise \#162}

This cruise has only a few deep stations, all just south of Iceland where natural variability is expected to be large. Based on this evidence, adjustments could not be considered for salinity.

\section{DI19890612, cruise \#166}

The mean of all crossovers is $-15 \mathrm{ppm}$, which is reflected in the corrections suggested by the inversions ranging between 15 and $20 \mathrm{ppm}$. As this is one of the earliest cruises in CARINA and the salinity in NADW mainly decreased during the 1990s, we chose to follow the higher of those suggestions. Based on this evidence, an adjustment of $20 \mathrm{ppm}$ was applied to the salinity data.

\section{OMEX2, cruise \#188}

The mean of all the crossovers is almost zero, which is quite different from the correction suggested by the inversion $(-10 \mathrm{ppm})$. The individual crossovers typically have small offsets at depths below $3000 \mathrm{~m}$, whereas in the shallower range included in the inversion, the differences tend to be larger. We ascribe these discrepancies to the variability of the Mediterranean outflow, which influences the area where this cruise was carried out. Based on this evidence, no adjustment was applied to the salinity data.

\section{Data access}

The complete CARINA database set is published at http:// cdiac.ornl.gov/oceans/CARINA/Carina_inv.html. It contains 188 individual cruise files in comma-separated, WHPO exchange format. Condensed metadata is contained in the header of each data file. In addition, the CARINA data set contains three merged, comma-separated, data files with the data products. These files are divided into the three geographical regions of CARINA. No special software is needed to access the data, but software for MATLAB users is offered at the site to facilitate reading of the data.

Acknowledgements. This work has been performed and funded as part of the EU project CarboOcean (Project 511176-2). Additional support from the International Ocean Carbon Coordination Project IOCCP (Maria Hood) and the Hanse Institute for Advanced Study (HWK Delmenhorst, Germany) are gratefully acknowledged. Additional support provided as follows for: A. Olsen, Research Council of Norway grant 178167/S30 (A-CARB); R. M. Key, NOAA grant NA08OAR4320752 and NA08OAR4310820; X. Lin, 
NOAA grant NA08OAR4310820; P. J. Brown, NERC Award NER/S/A/2004/12255; N. Gruber and I. Stendardo, ETH Zurich; A. Rios, A. Velo and F. Peréz, PGIDIT05OXIC40203PM Xunta de Galicia and CTM200627116E/MAR MEC; J. L. Bullister and R. Wanninkhof, NOAA Office of Atmospheric and Oceanic Research and Climate Program Office. Without the dedication and hard work of all investigators and analysts who collected the data used in this study, sometimes under adverse conditions, this project would not have been possible. We gratefully acknowledge those who have contributed their data to the CARINA project.

Edited by: V. Gouretski

\section{References}

Dickson, B., Yashayaev, I., Meincke, J., Turrell, B., Dye, S., and Holfort, J.: Rapid freshening of the deep North Atlantic Ocean over the past four decades, Nature, 416, 832-837, 2002.

Gouretski, V. V. and Jancke, K.: Systematic errors as the cause for an apparent deep water property variability: global analysis of the WOCE and historical hydrographic data, Prog. Oceanogr., 48, 337-402, 2001.

Johnson, G., Robbins, P. E., and Hufford, G. E.: Systematic adjustments of hydrographic sections for internal consistency, J. Atmos. Ocean. Technol., 18, 1234-1244, 2001.

Key, R. M., Kozyr, A., Sabine, C. L., Lee, K., Wanninkhof, R., Bullister, J. B., Feely, R. A., Millero, F., Mordy, C., and Peng, T.-H.: Results from the Global Data Analytis Project (GLODAP), Global Biogeochem. Cy., 18, GB4031, doi:10.1029/2004GB002247, 2004.

Key, R. M., Tanhua, T., Olsen, A., Hoppema, M., Jutterström, S., Schirnick, C., van Heuven, S., Kozyr, A., Lin, X., Velo, A., Wallace, D. W. R., and Mintrop, L.: The CARINA data synthesis project: introduction and overview, Earth Syst. Sci. Data Discuss., 2, 579-624, 2009,

http://www.earth-syst-sci-data-discuss.net/2/579/2009/.

McDowell, S. E., and Rossby, H. T.: Mediterranean water: an intense mesoscale eddy off the Bahamas, Science, 202, 10851087, 1978.

Olsen, A., Key, R. M., Jeansson, E., Falck, E., Olafsson, J., van Heuven, S., Skjelvan, I., Omar, A. M., Olsson, K. A., Anderson, L. G., Jutterström, S., Rey, F., Johannessen, T., Bellerby, R. G. J., Blindheim, J., Bullister, J. L., Pfeil, B., Lin, X., Kozyr, A., Schirnick, C., Tanhua, T., and Wallace, D. W. R.: Overview of the Nordic Seas CARINA data and salinity measurements, Earth Syst. Sci. Data, 1, 25-34, 2009,

http://www.earth-syst-sci-data.net/1/25/2009/.
Pierrot, D., Brown, P., Van Heuven, S., Tanhua, T., Schuster, U., Wanninkhof, R., and Key, R. M.: CARINA $\mathrm{TCO}_{2}$ data in the Atlantic Ocean, Earth Syst. Sci. Data Discuss., 3, 1-26, 2010, http://www.earth-syst-sci-data-discuss.net/3/1/2010/.

Richardson, P. L., Bower, A. S., and Zenk, W.: A census of Meddies tracked by floats, Prog. Oceanogr., 45, 209-250, 2000.

Sabine, C. L., Key, R. M., Johnson, K. M., Millero, F. J., Poisson, A., Sarmiento, J. L., Wallace, D. W. R., and Winn, C. D.: Anthropogenic CO2 inventory of the Indian Ocean, Global Biogeochem. Cy., 13(1), 179-198, 1999.

Sabine, C. L., Key, R. M., Kozyr, A., Feely, R. A., Wanninkhof, R., Millero, F., Peng, T. H., Bullister, J., and Lee, K.: Global Ocean Data Analysis Project (GLODAP): Results and Data, NDP-083, Carbon Dioxide Information Analysis Center, Oak Ridge National Laboratory, US Department of Energy, Oak Ridge, TN, 2005.

Steinfeldt, R., Tanhua, T., Bullister, J. L., Key, R. M., Rhein, M., and Köhler, J.: Atlantic CFC data in CARINA, Earth Syst. Sci. Data, 2, 1-15, 2010, http://www.earth-syst-sci-data.net/2/1/2010/.

Stendardo, I., Gruber, N., and Körtzinger, A.: CARINA oxygen data in the Atlantic Ocean, Earth Syst. Sci. Data, 1, 87-100, 2009 , http://www.earth-syst-sci-data.net/1/87/2009/.

Tanhua, T., Brown, P. J., and Key, R. M.: CARINA: nutrient data in the Atlantic Ocean, Earth Syst. Sci. Data, 1, 7-24, 2009a, http://www.earth-syst-sci-data.net/1/7/2009/.

Tanhua, T., van Heuven, S., Key, R. M., Velo, A., Olsen, A., and Schirnick, C.: Quality control procedures and methods of the CARINA database, Earth Syst. Sci. Data Discuss., 2, 205-240, 2009b, http://www.earth-syst-sci-data-discuss.net/2/205/2009/.

Velo, A., Perez, F. F., Brown, P., Tanhua, T., Schuster, U., and Key, R. M.: CARINA alkalinity data in the Atlantic Ocean, Earth Syst. Sci. Data, 1, 45-61, 2009a, http://www.earth-syst-sci-data.net/1/45/2009/.

Velo, A., Pérez, F. F., Lin, X., Key, R. M., Tanhua, T., de la Paz, M., van Heuven, S., Jutterström, S., and Ríos, A. F.: CARINA data synthesis project: $\mathrm{pH}$ data scale unification and cruise adjustments, Earth Syst. Sci. Data Discuss., 2, 421-475, 2009b, http://www.earth-syst-sci-data-discuss.net/2/421/2009/.

Yashayaev, I., van Aken, H. M., Holliday, N. P., and Bersch, M.: Transformation of the Labrador Sea Water in the subpolar North Atlantic, Geophys. Res. Lett., 34, L22605, doi:10.1029/2007GL301812, 2007. 